\title{
Previous diet of Royal Marine recruits in relation to training outcome
}

\author{
T. Davey ${ }^{1}$, A. Dziubak ${ }^{1}$, S. A. Lanham-New ${ }^{2}$ and J. L. Fallowfield ${ }^{1}$ \\ ${ }^{1}$ Institute of Naval Medicine, Crescent Road, Alverstoke, Gosport, Hants PO12 2DL and ${ }^{2}$ Nutritional Sciences Division, \\ University of Surrey, Guildford, Surrey, GU2 7XH, UK
}

Royal Marine (RM) recruits undergo 32 weeks of intense training, which continuously challenges and develops recruits, both physically and mentally, towards the ultimate goal of being awarded the Royal Marine Green Beret. A high quality diet during childhood and adolescence is essential to ensure optimal growth and development ${ }^{(1)}$. It was hypothesised that diet during this period may influence the ability of recruits to cope with the physical load of RM training. The aim of this study was to examine the relationship between diet during childhood and adolescence and the likelihood of recruits successfully completing RM training; this is part of on-going programme of research being undertaken by the Institute of Naval Medicine examining the dietary intake, nutritional status and bone health of Royal Marines.

RM recruits commencing training at the Commando Training Centre, Royal Marines, Lympstone, Devon were given an initial study brief, after which 1090 recruits from 20 Troops consented to participate in the study. Past dietary intake was self-reported using a validated Food Frequency Questionnaire ${ }^{(2)}$.

Past intakes of milk, milk products, fruit and vegetables were higher in recruits who completed training with their original troop, compared to recruits who took longer to complete training, or failed to complete training $(P<0.05)$.

\begin{tabular}{|c|c|c|c|c|c|c|c|c|c|c|c|}
\hline & & \multicolumn{2}{|c|}{$\begin{array}{c}\text { Milk } \\
\left(\mathrm{ml}^{-\mathrm{d}^{-1}}\right)\end{array}$} & \multicolumn{2}{|c|}{$\begin{array}{l}\text { Milk Products } \\
\text { (times.wk }^{-1} \text { ) }\end{array}$} & \multicolumn{2}{|c|}{$\begin{array}{c}\text { Vegetables } \\
\text { (times.wk }^{-1} \text { ) }\end{array}$} & \multicolumn{2}{|c|}{$\begin{array}{c}\text { Fruit } \\
\text { (times.wk }^{-1} \text { ) }\end{array}$} & \multicolumn{2}{|c|}{$\begin{array}{c}\text { Fruit Juice } \\
\text { (times.wk }^{-1} \text { ) }\end{array}$} \\
\hline & & Mean & SD & Mean & SD & Mean & SD & Mean & SD & Mean & SD \\
\hline \multirow[t]{3}{*}{$0-12$ Years } & All $(n=1029)$ & 522 & 282 & 4.3 & 2.1 & 4.4 & 2.1 & 4.4 & 2.1 & 4.1 & 2.2 \\
\hline & $\begin{array}{l}\text { Originals } \\
(n=343)\end{array}$ & 543 & 289 & $4.5^{*}$ & 2.1 & $4.6^{*}$ & 2.0 & $4.6^{*}$ & 2.0 & $4.3^{*}$ & 2.1 \\
\hline & Other $(n=686)$ & 512 & 278 & 4.2 & 2.1 & 4.2 & 2.2 & 4.3 & 2.1 & 3.9 & 2.2 \\
\hline \multirow[t]{3}{*}{ 12-18 Years } & All $(n=1029)$ & 654 & 301 & 4.3 & 2.2 & 4.9 & 2.1 & 5.1 & 2.1 & 4.6 & 2.1 \\
\hline & $\begin{array}{l}\text { Originals } \\
(n=343)\end{array}$ & $681^{*}$ & 305 & $4.6^{*}$ & 2.2 & $5.1 *$ & 2.0 & $5.3 *$ & 2.1 & 4.6 & 2.1 \\
\hline & Other $(n=686)$ & 640 & 299 & 4.2 & 2.2 & 4.8 & 2.1 & 5.0 & 2.2 & 4.5 & 2.2 \\
\hline
\end{tabular}

Note: * Significantly different to recruits who failed to pass out of training with their original troop $(P<0.05)$.

Further analysis is underway to examine the confounding effects of body composition on past consumption, but these suggest that diet during childhood and adolescence may influence the physical development and robustness of young males. In particular, a diet high in dairy products, fruit and vegetables during the years prior to commencing training may increase the likelihood of a recruit completing RM training with his original troop. These interesting findings certainly warrant further attention.

The authors would like to thank colleagues at the Commando Training Centre Royal Marines, Lympstone, Devon, for their support and assistance.

1. Golden BE (2000) Infancy, childhood and adolescence, in: JS Garrow et al. (Eds.), Human Nutrition and Dietetics 10th Ed, Churchill Livingstone, Edinburgh.

2. Leiper R, Fallowfield JL, Delaney S, Whittamore D, Dziubak A \& Lanham-New SA (2009) Institute of Naval Medicine Report 2009.017. 